\title{
School Architecture; Between Tradition and the desire of Contemporaneity
}

\author{
André SANTOS ${ }^{1}$, Catarina ALBUQUERQUE ${ }^{2}$, Jéssica \\ COSTA $^{3}$, Leonardo BARROS 4 \\ (1) Faculdade de Arquitetura, Universidade do Porto, Porto, Portugal \\ E-mail: amsantos@arq.up.pt \\ ORCID: https://orcid.org/0000-0002-1334-9813 \\ (2) E-mail: up201405384@arq.up.pt \\ (3) E-mail: up201504894@arq.up.pt \\ (4) E-mail: up201404032@arq.up.pt
}

\begin{abstract}
In the process of constant confrontation between traditional values and innovation in teaching-learning processes, after a long period in which the evolution of schools architecture in Portugal was characterized by high resistance to the transformations proposed, through the years, in 2007 was established a complete school modernization program. Promoting concertation and dialogue between Architecture and Education and summoning pedagogical models that aim to make teaching more flexible and attractive, this Program was designed to articulate the preexisting buildings with innovative spatial devices capable of responding to this purpose envisaging the school in the future. From the program's design to its implementation in each school, the dialogue was encouraged between tradition, the ideals of school and classroom rooted in the Portuguese cultural imaginary, and innovation, which urged due to the mismatch with contemporary expectations, educational in particular, and society in general. The intervention strategy, and the different lines of action, were developed in a way that it can be applied to all buildings, regardless of the different types that constitute the Portuguese school buildings universe, which, in addition to each authors interpretation and specificities, resulted in an enormous multiplicity of responses, in a strategy in which the tradition sustained the innovation.
\end{abstract}

Keywords: School Architecture, Educational Methods, Rehabilitation, Modernization, Future

\section{Introduction}

The Programa de Modernização de Escolas com Ensino Secundário (PMEES) ${ }^{1}$ was implemented in 2007 by the entity Parque Escolar E.P.E. Based on a conceptual and technical structure; this proved to be a unique and singular moment in the history of public-school buildings. Characterized by an extensive range of requirements, from the maintenance of the implantation territories and of a significant portion of the buildings, to the different characteristics of the pre-existences, the incorporation of the most recent regulatory impositions, the guarantee of improvement and rehabilitation of the civic, social and cultural relationship between the community and its environment, as well as the adoption of new pedagogical models, this Program claimed to be an opportunity to develop an interesting and complex critical process of cultural and architectural expression.

As a design and disciplinary practice, architecture has accompanied public-school buildings'

\footnotetext{
1 The Programa de Modernização das Escolas com Ensino Secundário (PMEES) was implemented in January 2007, based on the awareness of the state of high degradation of
}

transformation processes over the past few years through active intervention in their conception and planning. This performance allowed for critical reflection and thinking on the school architecture, focusing on developing methodology and producing innovative results. The challenge proposed motivated different design strategies, translated into more tailored options given each school's conditions, and each architect and its team paths(Toussaint, 2009).

For the first time in Portugal, a strategic plan was developed with different actors, political and economic, from the disciplinary universes of architecture and construction, and also from the pedagogical disciplinary fields, to ensure a higher quality of spaces and the possibility of pedagogical innovation. The existing buildings transmitted traditional educational ideals, characterized by the distance between the teacher and the students, inadequate for real needs. In addition to progress in pedagogical models, the need for change has become increasingly imperative due to the social and cultural changes taking place over the years,

the existing schools, aiming to intervene in 332 of the 477 secondary schools in operation in Portugal. 
reflecting both family and school lives. Since space, its value, shape, and material components must also constitute educational and orienting material, the will for change becomes opportune (Afonso \& Ladiana, 2011).

\section{PMEES}

Due to the innovative character of the project, framing in a diverse universe of buildings the ambition of modernizing the facilities, to induce educational changes in spaces, the Program constitutes a central element for the study of the relationship between education and architecture, as an innovative mean of materialization of models and educational ideals in high-quality learning spaces and school environments (Almeida, Blyth, Forrester, Gorey, \& Hostens, 2009).

The discussion between tradition and the need to innovate happened at several levels. First of all, in the teaching spaces, where it was necessary to produce changes in the teaching-learning models, regarding the way knowledge is transmitted and the role of control the teacher usually assumed facing the passive figure of the student, to ensure learning opportunities extend to all students, which favors their educational performance (Rodrigues, 2010). The changes aimed to produce a more participatory and attractive education, imposed a discourse between tradition and the opportunities to produce spatial changes.

The PMEES strategy reflects maintaining classrooms as a formal teaching space, evoking and retaining those spaces' traditions. Simultaneously, differentiated valences were added to be supported by a diverse typology of space, where a sense of spatial and functional innovation is explored (Santos, 2015a).

As a complement to traditional teaching inside the classroom, the Program also aimed to create informal learning spaces in diverse and flexible spaces, adapted to diverse teaching and ludic activities, and any transformations that might unfold in the school curriculum.

The Program also transports the dimension of inhabiting the school space, in contrast to traditional models, in which the home and school spaces were seen as antagonistic universes, responsible for different and incompatible levels of education - the first being in charge of the social training, in every dimension, and the second of formal schooling (Santos, 2015b). With changes in the family profile, in the reality experienced in schools, and in the socio-cultural paradigm, it was imposed to adapt the pedagogical structures, so that the school was accepted as a living space, a receptacle of habits, gestures, and actions repeated in time and space (Santos, 2015b). The objective of

2 The Organization for Economic Co-operation and opening the teaching space to the community arises from the belief that the two concepts - home and school - should unify.

\section{Pedagogical models - Between tradition and innovation}

\subsection{Tradition}

Until the end of the twentieth and the beginning of the twentieth-first century, the Portuguese school universe was characterized by traditional values and outdated pedagogies. Although it has become more inclusive and comprehensive, the school institution, up to a certain point in history, was linked to an equipment ideal for projecting the State's power, tradition, directed, specifically, to the social elites.

School buildings mark this time due to their constructive and built typologies, conditioned by each epoch's political and socio-cultural principles. In the case of Portugal, we face an enormous diversity of architectural values, even contradictory. Although the predominance of normalized responses characterizes the built patrimony, there are several different spatial and functional typologies.

Several typologies constituted the universe, space, and teaching-learning methods that characterize them do not differ. The current pedagogical models are limited to spatial and functional organization ideals capable of transmit power, discipline, and homogeneity among students, prevailing a rigid dynamic of knowledge transmission.

In this context, the classroom assumes itself as the only spatial condition for the teaching function. The current expository learning model transmits and instills an austere environment from the spatial organization to the furniture. It constitutes the symbol of spatial tradition, characterized by the rigid organization, composed of aligned secretaries, by the podium, which elevates the teacher, distinguishing him from the students and the black slate board. The symbolism of this space was reinforced by elements such as the flag or the cross - inherited by an idea of tradition built and fed by the conservative and oppressive ideologies prevailing during the period in which the public school universe grew.

In the history of the evolution of the Portuguese school building, the attitude of considering a new pedagogy and, consequently, architectural response finds in the decades of 1960 and 1970 a moment of experimentation. The pilot school of Mem Martins led this, and the P3 project of schools, both coordinated by the architect Maria do Carmo Matos.

The contacts with the Organization for Economic Co-operation and Development $(\mathrm{OECD})^{2}$ allowed 
Portugal to participate in the project Development and Economy in Educational Building (DEEB) ${ }^{3}$, starting in 1963 . The aim was to build several schools, which would allow, from the analysis of their occupation and forms of usage, find relationships between architectural solutions and pedagogical practices, to normalize and typify the school space. The project consisted of articulating four teaching cells clustered by a central space, constituting a moment of entry and an uncovered patio. With the ambition of incorporating open spaces, each cell established a relationship with the unique common space, materialized by a multipurpose room. The model, whose merits of articulation between what is necessary for the pedagogical activity and the required space and equipment has been recognized by the OECD technicians (Oddie \& McDowall, 1968), met enormous resistance from the prevailing educational models. For that reason, it was only built the school of Mem Martins ${ }^{4}$.

Under the initiative of the Direcção-Geral das Construções Escolares (DGCE) ${ }^{5}$, in the early 1970s, the P3 project $^{6}$ was developed, which constituted another example of a standardized proposal for primary school architecture, based on the experience of Mem Martins school. The first school was built in Quarteira. As in the previous project, its main objective was to provide flexibility and spatial diversity, using a conceptual and constructive system based on modular strategies to achieve that goal and optimize and reduce costs effectively. This option steams from an articulation of different autonomous nuclei, minimizing the space intended for circulation, to allow the buildings to have a longer life, that would not conditionate the evolution of educational processes (Gonçalves, 2011).

The solution based on modular strategies and standardization principles that, in Portugal, started with these experiences, are based on the English experience of expensive construction that, guided by the principles of constructive rationality and const optimization, led the school construction in the period that followed the second world war. These constructive objectives were also

administer and manage the funds from the Marshall Plan, destined to European reconstruction and to stimulate economic activities in the post-world war period. Currently, with the voluntary participation of thirty-four countries, it identifies, discusses, and analyzes problems in specific workgroups, to promote measures for their resolution.

${ }^{3}$ The Development and Economy in Educational Building, started in 1953, aiming to provide technical support for the development of school projects and planning in the Mediterranean countries, including Portugal.

4 The Mem Martins pilot school project, inaugurated in 1966, embodies and attempt to plan and rationalize a specific program, based on educational regulations accompanied by other of a pedagogical nature, with the same objective of creating open and flexible spaces (Santos, 2015a).

Both architectural experiences did not find the necessary foundations to develop and consolidate. Given the enormous resistance to the new teaching-learning processes that these spaces allowed, they were rejected. It is necessary to understand that this rejection is, to a large extend, justified by the incompatibility with the restrict and undemocratic models in force, by the cultural values instigated by the regime, and by the accommodation to the prevailing pedagogic practices that have not accompanied the changes of architecture, maintaining the traditional methods (Martinho \& Silva, 2008).

These experiences consolidated the belief that architectural innovation would have to be supported by social, cultural, political, and pedagogical innovation for this transformation to be legitimate.

\subsection{Innovation}

When physical learning environments offer resources and possibilities that support new teaching methods and learning goals, schools are much more prompt to change their operational culture. (Kuuskorpi \& Gonzáles, 2011, p. 4)

Currently, the school's identity has detached itself from all prejudices and paradigms associated with tradition as equipment of discipline and power, seeking to take the role of inclusive equipment at the service of culture and education, promoting the most varied activities in its spaces. Educational models evolve to implement collaborative and exploratory practices, highlighting the student's identity as a transmitter and transformer of their learning process instead of the ancestral teachinglearning model.

The technological innovation has provided quick access to different information channels, allowing control and possession of different pedagogical instruments. Thus, the traditional school institution loses its exclusivity in transmitting knowledge, leading to a total expropriation of its spaces and teaching methods. This issue was the subject of reflection on the space reorganization process

resulting from the participation in the DEED project.

5 The Direcção-Geral das Construções Escolares was created in 1969, with the purposed of managing the Portuguese school patrimony. It played a decisive role in the development and implementation of standard projects, in which a pragmatic response was developed, facing the economy and the speed of execution.

6 The P3 project, created in the early 1970s, was responsible, until 1985, for the construction of around 370 schools throughout the national territory. Through a modular strategy, the project idealized the establishment of a school with open spaces, with the main objective of providing flexibility and spatial diversity. 
since the learning process has become decentralized and can occur anywhere.

Motivated by the search for a contemporary pedagogical program, it was sought to create lines of action that could compound the school's new identity. Thus, five strategic objectives were found, which briefly describe the innovation and spatial transformation of the new school, designed for the future: flexibility and adaptability; the adoption of information and communication technologies; classroom and informal teaching spaces; creative and stimulating spaces; openness and sharing with the community; and, lastly, comfort conditions (Heitor, 2011).

In 2005, with the possession of the XVII Constitutional Government, it was decreed the intent to invest in structural changes, to achieve a universally accessible quality education (Presidência Conselho de Ministros, 2005). It was then mobilized to raise awareness of the Portuguese school patrimony state, aiming to understand each school's needs and problems. The state of degradation verified was justified by the absence of a global strategy, which is considered a maintenance plan, integrated and aware of the various schools' different typologies over the years. Starting from the analysis of pre-existences, three objectives were defined to be implemented: optimize the school network and extend the minimum schooling; increase teaching-learning processes efficiency; and promote a learning culture. Aiming to stimulate attractiveness and innovation, the goal was to project the in future, promoting physical and pedagogical durability of the buildings, diversifying the educational odder through the relationships with the communities and reinforcing the diversity and flexibility of the educational offer, providing the installations with a technological framing capable of responding to contemporary models, as well as refocusing the school building in the urban fabric and open it to the communities.

It was assumed as national urgency to overcome the educational backwardness concerning European standards, integrate all children and young people in school, and provide them with a motivating, demanding, and rewarding learning environment, progressively improving results, raising the next generations' training qualifications. Overcoming these challenges is an essential objective for each individual's personal and civic development, promoting science and culture and

\footnotetext{
${ }^{7}$ Herman Hertzberger (1932) is an architect trained at Delft University of Technology, in the Netherlands (1958). Among his works, stand out the Montessori school, in Delft (1966-70), the Central Beheer building, in Apeldoorn (1972), and the Chassé Theater, in Breda (1995).

8 Maria Montessori (1870-1952) was an Italian physician and educator trained at Sapienza Università di Roma
}

society's cohesion, productivity, and economic competitiveness (Presidência Conselho de Ministros, 2005).

To implement all the proposals and paradigms mentioned, a program was built to establish the parameters to guide the interventions. The PMEES was developed and executed by Parque Escolar, which, unlike previous school construction plans, aimed at a participatory model, detaching itself from any mechanism of exercise of state power.

\subsection{PMEES implications on the spatial characteristics of the school buildings}

... how does the environment shape the learner, and, in turn, how does the learner influence the learning environment? In other words: what is the transactional relationship of the learning environment? (Lippman, 2010, p. 1)

The conceptual model of school space reorganization adopted by Parque Escolar was based on three principles: the articulation of different functional sectors (academic and nonacademic areas); the guarantee of conditions for its integrated operation; and the possibility of opening some sectors to use by the exterior community (Heitor, 2011).

The school's different functional spaces related to pedagogical practices translate into the distinction and categorization of different learning moments. Therefore, different spatial typologies were defined corresponding to three teaching modes: formal curriculum, that represents the need for a ser of traditional spaces; informal curriculum, that arises from the ambition to develop learning processes in spaces outside the classroom, which takes place in areas of circulation and coexistence; and the hidden curriculum, that arises from the stimuli precepted when going through the school space (Santos, 2015a).

The three requirements listed above, as well as the articulation of the different pedagogical requirements, found the answer in the adoption of the concept of learning street, introduced by the architect Herman Hertzberger ${ }^{7}$ in the Montessori School, in Delft, the Netherlands, in the 1960s, based on the ideals of Maria Montessori ${ }^{8}$ (Heitor, 2011). This structure, which consolidates the exhibition, the exposition, and the meeting inside a large covered area, is the mediating element of the relationships established between the different spaces, formal and informal, interior and exterior,

(1896). She developed experiences and proposals for pedagogical philosophies based on a human development model through interactions with the environment, to explore the innate capacity that children have for cognitive development. Based on her ideas, the Montessori pedagogical method has been widely disseminated since the twentieth century. 
throughout this commentary street, to which classrooms are associated as small autonomous units (Taylor, 2009; Hertzberger, 1991).

It is evident, in the conceptual model, a functional hierarchy. It is reinforced the existence of a spatial nucleus of formal learning, for which a set of teaching spaces and equipment with appropriate characteristics is necessary, in dialogue with the informal learning nucleus.

The way other school spaces are organized has a significant impact on more informal learning opportunities, encouraging students and teachers to stay in school longer and participate in activities that encourage a learning culture (Heitor, 2011).

The Program foresees that the resulting spaces would be attractive for promoting acceptable teaching practices and flexible, to adapt to possible changes in the school curriculum, and for the active involvement of students and teachers in improving pedagogical processes. Spatial multifunctionality allows diverse and transversal use by all school communities (Heitor, 2008).

This way, the adoption of the learning street model, due to the range of spatial possibilities that unfolds in the analysis of each intervened school, gives space for the ambition to incorporate informal learning mechanisms. With the implementation of the model, it is possible to promote a diversity of activities of a collaborative, exploratory, and experimental nature (Heitor, 2011).

Within the Program, a hierarchy of the various space sectors was structured, defining the accessibility level to each of them. The first levels are composed of the reception and administration areas, followed by informal learning spaces, comprising the library and other social spaces, sports pavilions, and auditoriums. The last level is made up of formal learning areas, mainly classrooms.

For the communities external to the school to participate in academic and non-academic activities, it is a programmatic objective to open spaces to them, such as the library, the auditorium, the sports pavilion, and the museum areas. Allied to this question, there is also the ambition to make all spaces, social and academic, inclusive, with easy and safe access to restricted mobility and special educational needs.

The library should be defined as the institution's symbolic center, the most important space of knowledge, with a materialization that places it in the school building physical center. This space is intended for universal access with a central role in the school's spatial and functional organization. To this end, it must assume a prominent material formalization and claim protagonism in the interior's image to the exterior of the school lot.

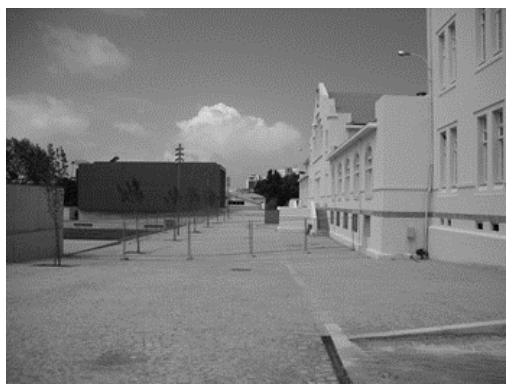

Fig. 3 Open path to the city inside the school lot. Escola Secundária Rodrigues de Freitas, Architect Manuel Fernandes Sá (2009) C) André Santos

Within the perspective of promoting the participation and inclusion of all social groups in school life, other spaces of public access, intended for cultural and sporting events, as well as to administrative, management, or service functions, should be articulated, through the learning street, with the entrance space, in a harmonious and appealing architectural composition.

\section{Contributes from the past in the construction of the future \\ 4.1. Rehabilitation}

The challenge proposed to the project teams was to rehabilitate the existing structures, which entailed the obligation to attest to the state of the preexisting structures and reflect on each of the building's heritage values.

This reflection started with the program's design, with the distinction of three construction periods and identifying the spatial and imagistic properties shared by most schools built in each time interval. This cataloging allowed the structuring of the Program to meet the general expectations of every school space (Heitor, 2012).

The defined groups denounce typological differences, from historical collegial buildings, built until 1936, in large lots in areas of strong urban centrality, to those destined to technical and commercial schools, built from 1936 to 1968, or those that, constituting $77 \%$ of the entire universe, are the result of the typification programs that have been multiplying since the 1970s (Santos, 2015).

Having identified the typological variety of the structures in question and having the Program been designed to suppress all schools' needs, the challenge of identifying the values that deserved to be preserved within these interventions was imposed on the architecture. For the most diverse reasons, for example, the quality of the building, its implantations, or its value in the conformation of the urban and social space, there was a concern to maintain the image characteristics in many schools. 


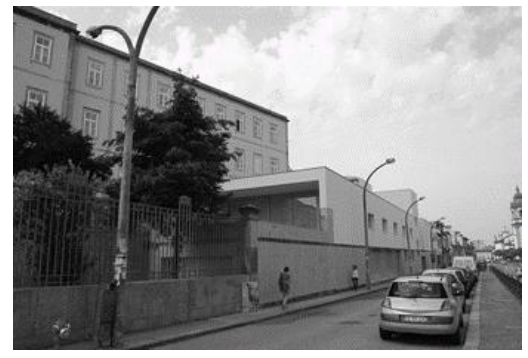

Fig. 4 Connection between the school and the city. Escola Secundária Sá de Miranda, Architect Bernardo Távora (2012) @ André Santos

The secondary schools Rodrigues de Freitas, in Porto, and Sá de Miranda, in Braga, are examples of actions of rehabilitation of historic buildings, belonging to the first group of schools built before 1935, and, although in different urban situations, the two buildings play an enormous role in building the identity of the cities. There was an evident concern in both interventions to value the significant patrimonial value, which was even spread and concealed in the urban fabric in the first. In this intervention, there was particular attention to affirm the building's urban commitment by redesigning the adjoining public space, participation in conforming paths in the city, and redefining the various urban fronts. In both contexts, there was the addition of new bodies that assume the contemporary condition, although with totally different formal and symbolic performances. While at Rodrigues de Freitas school, the new body, which announces Porto's Conservatory of Music, distances itself significantly from the original, not only in material, but also composition and color; at Sá de Miranda school, the body built on the street front, although with different compositional language, adopts materials and chromatic pallets for the original, and assumes the role of connecting the school with the public space, so that the existing building is highlighted.

Since these are rehabilitation operations, it was was mandatory to maintain a significant part of the original structure in the new compositions. This way, whether it was taken a position of preservation or assumed a position of disguising the original and renovate the image, the architects were led to defining what was to recover carefully and the little that was to be demolished.

The secondary schools of Lousada and Garcia de Orta are examples of interventions in structures of mediocre architectural quality, resulting from the standardization programs of school buildings. However, the design options assumed bt the authors were quite different. Whereas the structural, rhythmic, and volumetric rules are accepted and preserved in the Garcia de Orta school, that, thus, assumed an image, albeit refreshed, that makes a clear reference to the history of the institution, the position taken in the school of Lousada is of total imagistic transformation in face of the pre-existence. By adding bodies that make the original volumetric reading impossible and accepting a skin that completely changes the building's image, this intervention takes a clear cut with the past.

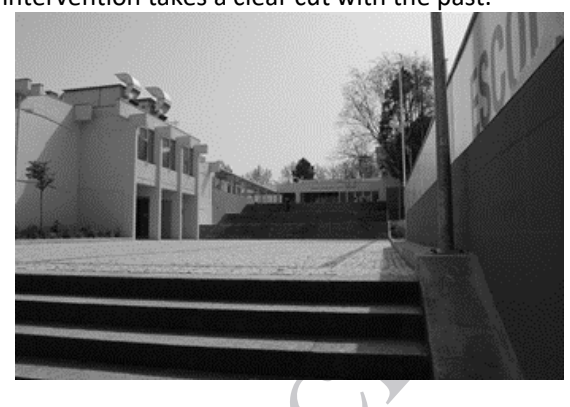

Fig. 5 Respect for history. Escola Secundária Garcia de Orta, Architect Ricardo Bak Gordon (2011) (C) André Santos

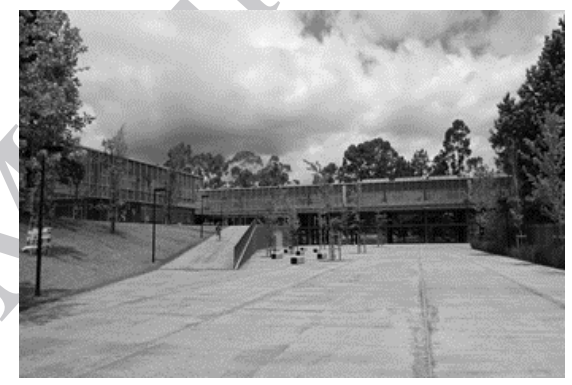

Fig. 6 Complete transformation of the school image. Escola Secundária de Lousada, Architect José Manuel Carvalho Araújo (2012) (C) André Santos

\subsection{Paradigm transformation between Architecture and Education}

Whichever the typological basis, the context, and the author's position regarding the pre-existences, as we saw earlier, the programmatic and conceptual frame is transversal to all interventions. This way, given the multiplicity and diversity of results, it is understood that the specificities of the Program did not contribute to a homogenization of results; on the contrary, it led to a demanding challenge to the architecture.

The articulation of traditional teaching models with the new pedagogical paradigm has benefited from accepting traditional classrooms as an integral part of the formal curriculum. Therefore, although under the requirement of adaptation to the most recent technological requirements, comfort, and, many times, dimensions, it was allowed to preserve a substantial part of the existing classrooms. 
The general need to expand the teaching, social and administrative areas allowed, with natural differences in each school's requirements, that the new spaces could be used to optimize this programmatic articulation. In these moments, in general, the learning street is unfolded, as a hinge connecting space and as a creator of different spatial situations.

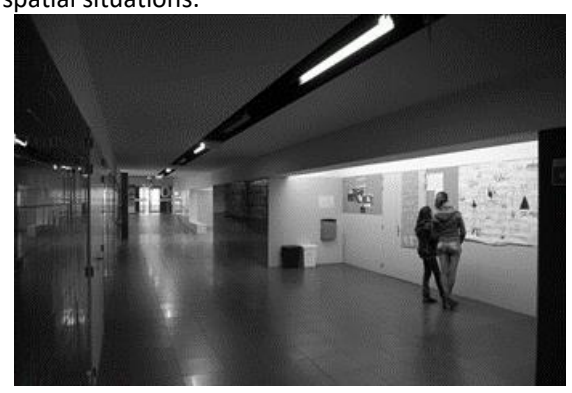

Fig. 7 Learning street. Escola Artística Soares dos Reis, Architect Carlos Prata (2012) @ André Santos

The artistic school Soares dos Reis is a paradigmatic example of adopting the conceptual mechanism of learning street. In a unifying composition, the additions made, in total compositional agreement with the two preexisting parallel volumes, essentially function as a distributive and connective system of all programmatic valences. Due to the enormous plastic liberty, several spatial moments are multiplied along this axis, contributing the articulation with singular spaces, such as the auditorium, the library, and the exhibition gallery.

\section{Final Considerations}

From the developed approach, it is understood that the Portuguese school has undergone, in recent years, a tremendous change at all levels, from the updating of teaching models, the ways of usage and appropriation of space, to the questions related to architecture, spatial configuration, comfort or even image. More than that, it is clear that this complex transformation process, that aims at all levels, the innovation and creation of school environments that respond to contemporary challenges and that validate the construction of the future, is based on the past, in the history of education in Portugal and of each of these schools.

Based on these changes, it is comprehensible that many proposals and experiences, with greater or lesser success, have been multiplied in Portugal and Europe. In fact, experiences such as the pilot school of Mem Martins and the P3 project, which were developed in a contemporary period of the proposals of Herman Hertzberger, already proposed, with their spatial configurations, enormous changes in the teaching-learning processes that were only partially confirmed with
PMEES, already supported by the ambition to promote educational changes from the Portuguese state, and not by European initiative.

The fact that this Program for the renovation of the Portuguese school patrimony promotes rehabilitation, with the obligation to maintain a considerable part of the building, allowed a deep reflection on the values of the Portuguese school tradition that would be worth validating. Indeed, the traditional school structure, particularly the classroom, constituted a basis for all the spatial, technical, and procedural innovations developed. It is in tradition, which proved to be immensely operative for this process, that, in this process, the key to building the future was found.

\section{References}

Afonso, R. B., Ladiana, D. (2011). Que espaço para a escola? In Afonso, R. B., Ladiana, D. (org.) O espaço da escola (pp. 204-208). Florença: Alinea Editrice. ISBN: 978-88-6055-666-0.

Almeida, R., Blyth, A., Forrester, D., Gorey, A., Hostens, G. (2009). OECD/CELE review of the secondary school modernisation programme in Portugal. CELE Exchange. Paris: OECD. Retrieved from URL: http://www.oecd.org/portugal/44247100.pdf

Gonçalves, R. C. (2011). Arquitetura flexível e pedagogia ativa: um (des)encontro de espaços abertos (Doctoral dissertation). Lisboa: Instituto de Educação da Universidade de Lisboa.

Kuuskorpi, M., González, Nu. C. (2011). The Future of the Physical Learning Environment: School Facilities that Support the User. CELE Exchange. Paris: OECD. Retrieved from https://www.oecdilibrary.org/education/the-future-of-the-physicallearning-environment_5kg0lkz2d9f2-en

Lippman, P. (2010). Can the Physical Environment Have an Impact on the Learning Environment? CELE Exchange. Paris: OECD. Retrieved from https://www.oecd-ilibrary.org/education/can-thephysical-environment-have-an-impact-on-thelearning-environment_5km4g21wpwr1-en

Heitor, T (2008). Modernising Portugal's Secondary Schools. Paris: OECD, ISSN 1609-7548.

Heitor, T. (coord.) (2011). Parque escolar 2007-2011. Intervenção em 106 escola. Lisboa: Parque Escolar E.P.E., Direção Geral de Projecto - Área de Edificações. ISBN 978-989-96106-6-8.

Heitor, T, Pinto, R. M. (2012). Thinking critically towards excellence in school buildings using space syntax as a catalyst for change. Santiago: M. Greene, J. Reyes and A. Castro.

Hertzberger, H. (1991). Lessons for students in architecture. Rotterdam: 010 Publishers. ISBN: 97890-6450-562-1.

Martinho, M., Silva, J. F. (2008). Open plan schools in Portugal: failure or innovation? In Yelland, R. (dir.). PEB Exchange, 64. Paris: OECD. Retrieved from www.oecd.org/portugal/41533062.pdf>. ISSN: 1609-7548

Oddie, G., McDowall, D. (1968). Development and Economy in Educational Building in Greece, Portugal, Spain, Turkey and Yugoslavia. Report on OECD project. Paris: OECD. Retrieved from 
http://files.eric.ed.gov/fulltext/ED046104.pdf Presidência do Conselho de Ministros (2005). Programa do XVII Governo Constitucional de 2005-2009. Retrieved from https://www.historico.portugal.gov.pt/pt/ogoverno/arquivo-historico/governosconstitucionais/gc17/programa-dogoverno/programa-do-xvii-governoconstitucional.aspx

Rodrigues, M. L. (2010). A escola pública pode fazer a diferença. Coimbra: Edições Almedina S.A. ISBN 978-972-40-4285-5.

Santos, A. (2015a). Similaridades e singularidades na reabilitação arquitetónica do parque escolar Programa promovido pela Parque Escolar, E.P.E. no norte de Portugal (2007-2011). (Doctoral dissertation). Porto: Faculdade de Arquitectura da Universidade do Porto.

- (2015b). Habitar o espaço público: a escola como casa. In Resdomus. 2, article n. 3 (pp. 21-29). Porto: FAUP publicações.

Taylor, A. (2009). Linking architecture and education. Sustainable design of learning environments. Albuquerque: University of New Mexico Press. ISBN: 978-0-8263-3407-7.

Toussaint, M. (2009). Projetar para adequar à contemporaneidade. In Escolas Secundárias Rabilitação. Casal de Cambra: Caleidoscópio Edição e Artes Gráficas, SA (pp .23-24). ISBN 978-989-658050-6. 